\title{
Do Internet and Human Capital Matter for Economic Growth in Developing Countries? Empirical Evidence from WAEMU Countries
}

\author{
Kuawo-Assan Johnson \\ Enseignant-Chercheur à la Faculté des Sciences Economiques et de Gestion de l'Université de Kara, Kara, Togo \\ Email: dan_kjohns@yahoo.fr
}

How to cite this paper: Johnson, K.-A. (2016) Do Internet and Human Capital Matter for Economic Growth in Developing Countries? Empirical Evidence from WAEMU Countries. Modern Economy, 7, 1186-1197.

http://dx.doi.org/10.4236/me.2016.711116

Received: August 30, 2016

Accepted: September 25, 2016

Published: September 28, 2016

Copyright $\odot 2016$ by author and Scientific Research Publishing Inc. This work is licensed under the Creative Commons Attribution International License (CC BY 4.0).

http://creativecommons.org/licenses/by/4.0/ (c) (i) Open Access

\begin{abstract}
In the attempt to establish new sources of economic growth in the West African Economic and Monetary Union (WAEMU) countries except Gunea Bissau for sustainable growth of the region, this study aims to empirically assess the role of internet and revisit the impact of human capital in these countries based on panel data from 2009 to 2014 . We firstly use the principal component analysis technique to build the internet network development index and the human capital index. Then we estimate a Cobb-Douglas function under the neoclassical Solow model to establish the relationship between gross domestic product and internet and human capital by using the fixed effects estimation technique. The findings indicate that internet network development constitutes an important pillar for economic growth in WAEMU countries at the current prevailing economic environment. In addition, they reveal that the performance of human capital in terms of economic growth is weak, a result which can be attributed to the poor quality of educational systems of the union. Physical capital is another source of economic growth of the WAEMU countries established by this study. Policy message drawn from this study encourages strategies aiming to strengthen internet network development in WAEMU countries.
\end{abstract}

\section{Keywords}

Economic Growth, Human Capital, Internet, Togo

\section{Introduction}

The West African Economic and Monetary Union (WAEMU) is a West African regional organization comprised of eight countries that are: Benin, Burkina Faso, Cote d'Ivoire, Guinea Bissau, Mali, Niger, Senegal and Togo. These countries share the same 
money (West African francs, CFA francs), the same monetary policies implemented by the West African Countries' Central Bank (BCEAO), a unique central bank, and the same language (French). The main objective of the union is to promote regional economic integration and create common market. By doing this, WAEMU organization policymakers seek good economic performances mainly in terms of economic growth. However, the union is struggling to obtain a high and sustainable economic growth for a relatively long period as one can easily deduct from Figure 1 below.

Thus, the traditional economic growth pillars seem insufficient to achieve this crucial objective. Indeed, the recent efforts of the union in physical capital accumulation and investment in human capital have not been associated with a sustained high economic growth. For instance, while between 2008 and 2012 the physical capital accumulation increased by 3.4 percent of the GDP, the economic growth decreased by 3.6 (BCEAO, 2015). Therefore, WAEMU needs to find new direction to shift the way of economic growth, and the internet as an important component of communication technology information can serve this role given its potential benefits in terms of E-commerce, information dissemination and spillovers. Consequently, this paper investigates the impact of internet development on economic growth of WAEMU countries. To our knowledge, such a study does not exist even though its findings could strongly guide economic policy formulation of the union. In addition, because of the controversial effect of human capital, this study revisits the role the human capital plays in economic growth performance of the region. In this study we refer to WAEMU countries except Guinea Bissau as WAEMU_ and this notation is retained for the remaining of the paper since Guinea Bissau is excluded from the study because of the lack of data regarding this country.

The remainder of the paper is organized as follows: the following section presents the related literature review, section 3 specifies the model while section 4 establishes theoretical relationship between GDP and the target variables. Variables construction and data analysis are done in section 5. Section 6 discusses estimation results. The paper ends with a conclusion.

\section{Related Literature Review}

\subsection{Glance on Studies Related to Internet Impact on Economic Growth}

Even though the empirical assessment of internet development impact on economic

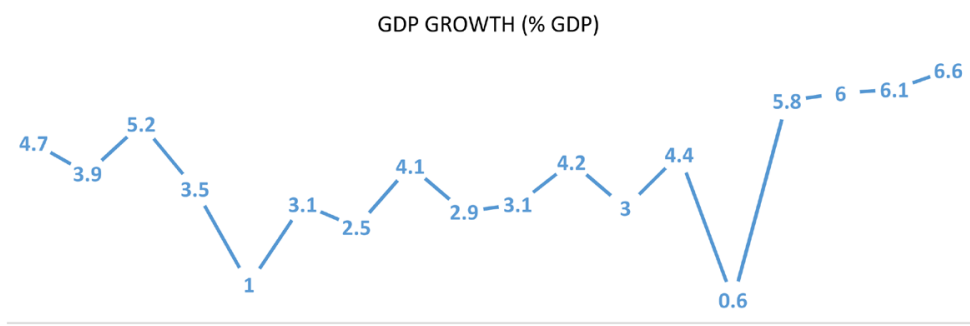

199819992000200120022003200420052006200720082009201020112012201320142015

Figure 1. Glance on WAEMU economic growth from 1998-2015 
growth in WAEMU countries is completely a new topic, several studies all over the world have tried to explore the area but their findings are often contradictory.

Studies related to the impact of Information communication technology (ICT), including internet, on economic performance can be grouped into macro-level and micro-level. At the empirical macro-level, authors who focus on developing and emerging countries examine different country groups and time periods. The study by [1] reveal that ICT stock of capital have a positive impact on GDP only in developed countries. For the authors, this finding is explained by potential missing of IT-enhancing complementarity factor such as human capital. Contrary to this previous finding of [1], [2] study's results support the hypothesis that there is not any relationship between ITC and economic growth in neither developed nor developing countries. This finding is possibly explained by the measurement of ICT which is approximated by the share of nominal ICT investment in GDP. Indeed, this measurement is questionable because it does not include any ICT quality improvement over time. According to the results of the study of [3], ICT has a positive impact on labour productivity growth in both developing and developed countries but its effect is higher in developed countries. The study of [4], based on data relative to upper-income developing and developed countries for the period 1994-2007, provide econometric evidence of the positive impact of ICT on economic growth in developed and developing countries. Finally, the paper by [5] reveals that ICT has positive impact on emerging, developing and developed countries taken as a whole. However, this positive effect disappears once regressions are made for the subsample of developing, emerging and developed countries.

In addition to the previous macro-level studies mentioned above, a number of several studies exist on the role of ICT in economic growth. In his thesis, [6] analyses the relationship between telecommunications and development in Cote d'Ivoire. Base on his results, he concludes that telecommunications are valuable tools that can help build development dynamics. [7] discusses the impact of the rapid diffusion of mobile phone usage in Sub-Sharan Africa. [8] analyses empirically the impact of ICT capital on productivity of firms in Brazil and India. They find a positive impact. [9] studies the relationship between internet communication technology and economic growth in China with the help of Cobb-Douglas function under slow model and concludes that internet communication technology has a positive role in promoting economic growth in China. In the same line, [10] analyses the impact of "internet plus" in Chinese economy development and conclude that with "internet plus" time coming, China economy development will be related to internet tightly in current time and future.

\subsection{Glance on Studies Related to Human Capital Impact on Economic Growth}

In studies of a wide range of countries, developed and developing, the common measures of human capital based educational performance appears to have in the long term, a uniform significant positive effect on GDP and, transitory a positive effect on economic growth during the process of convergence toward the steady state [11]. This is 
the best effect a variable as human capital can have on economic growth in a neoclassical framework, because the long-term economic growth is only determined in this model by the technological progress [12]. However, one of the most surprising results of empirical studies of human capital and growth is that when the study sample is limited to OECD countries, the effect of human capital on economic growth is insignificant, null or even negative [13]. We find a good example in [11] in which the estimate of the effect of human capital amounts to 0.0000 for a sample of OECD countries. This negative result could be explained, among other factors, by the fact that we cannot directly measure human capital because, unlike other economic goods, human capital is not commonly exchange in markets. This is why we usually measure human capital indirectly, approximating it by education levels and enrolment rates. However, these human capital indicators are not necessarily comparable on a transnational scale because of the wide variety of educational systems around the world. It is not very easy, for example, to compare the Anglo-Saxon education system to the French one. In an article, [14] has even asked "where has gone education?" He identifies three main explanations of why the most robust econometric analyses do not provide a stable and positive relationship between human capital and economic growth, these are:

- The increase in individual salaries can lead to decay of the country if new graduates are moving to "unproductive" sectors;

- If despite the increase in educated population, the private sector does not need new skilled workers, what is most often the case in developing countries, an unexpected drop in education yields can occur ex post and thus the contribution of individual gain may be smaller than what would have been predicted ex ante.

- The quality of education can be so low that skills required to lead to economic growth do not exist.

In a paper on the topic, [15] address the issue of data quality and conclude that the effect of average schooling indicators on growth, adjusted for measurement errors, is positive and significant in 21 countries of OECD.

Other studies have also analysed the impact of human capital on economic growth. Thus, [16] show that investment in human capital and physical capital contributed in explaining economic growth rates of the USA to nearly 83\% between 1948 and 1986. [17] also shows that a $1 \%$ increase in high school enrolment is associated with an increase of $2.5 \%$ to $3 \%$ of the GDP growth rate.

Similarly, a study in Togo shows that human capital has a significant effect on the fluctuations of economic activity but does not influence the long-term growth [18]. Such a result of the impact of human capital on growth can be explained by either, misuse of human capital accumulated, or by the brain drain, which should normally constitutes this type of capital. However, this study presents considerable drawbacks. Indeed, in the estimation of the growth model, the variable used as a proxy to measure the impact of human capital on growth by the author is the secondary education. Such a variable, although it can have an impact in some countries can have very mixed effects in developing countries especially where French secondary education remain gen- 
eral. The result is that the skills and knowledge in such a system cannot be approximated by the size of the secondary education given its low productivity. Thus, use such a variable as human capital proxy, in our opinion, may create a risk of underestimating the actual contribution of human capital in the country's economic growth, which can lead to biased conclusions.

[19] isolates the effect of human capital on economic growth in WAEMU countries using endogenous growth model. Surprisingly, the author finds that human capital has a significant negative effect on economic growth. This paradox is explained by the education quality problem. [20] discusses the role of human capital in developing countries shifts attention to issue of school quality, area in which developing countries have been much less successful in closing the gap with developed countries. The author recommends developing world to improve school quality in order to improve their economic performance. [21] assesses the specific contribution of the various education levels to economic growth in Togo for the period 1980-2012 using slow model. Based on the results, the author concludes that only the primary education has significant impact on economic growth.

\section{Model Specification}

The empirical analysis of this study is based on the model used by [22]. This model is constructed on the basis of classical Cobb-Douglas functional form. Education level of labour force is accounts in human capital. The basic specification of the model is:

$$
Y_{i t}=A_{i t} * K_{i t}^{\alpha} * H_{i t}^{\beta}
$$

$Y_{i t}$ represents real GDP to capture economic growth, $K_{i t}$ physical capital, $H_{i t}$ is the average educated years of the considered countries. Because this study aims to assess in addition to the impact of human capital, the role internet plays in driving economic growth, it is necessary to consider this factor in the model. In order to avoid misleading results we included several control variables in addition. The control variables included are: R \& D investment and transportation. Total Factor Productivity technique is used to alter the basic model specified in Equation (2). The TFP represented by $A_{i t}$ is defined as follow:

$$
A_{i t}=A \mathrm{e}^{\rho_{1} \text { Internet_index } x_{i t}+\rho_{2} \text { Intch }{ }_{i t}+\rho_{3} \ln \operatorname{Trann}_{\mathrm{it}}+\gamma_{i}+\varepsilon_{i t}}
$$

Internet $_{\text {it }}$ index measures the internet network development, Intch $_{i t}$ measures the technology progress, InTrans ${ }_{i t}$ transportation capacity, $\gamma_{i}$ represents fixe effects which is determined by country specific economic development. Applying log function to the equations 1 and 2 and combining them leads to the final functional form specified bellow:

$$
\begin{aligned}
\operatorname{LnY}_{i t}= & \operatorname{LnA}+\alpha \operatorname{LnK}_{i t}+\beta \operatorname{LnHC}_{i t} \text { index }_{+} \rho_{1} \text { Internet }_{i t} \text { index } \\
& +\rho_{2} \text { Intch }_{i t}+\rho_{3} \text { InTrans }_{i t}+\gamma_{i}+\varepsilon_{i t}
\end{aligned}
$$

Model 3 is used for empirical analysis. 


\section{Theoretical Relationship between Variables of Interest and Economic Growth}

It is sound to look deeper into the relationship between human capital and economic performances in terms of economic growth. This is to answer to the question: What are economic implications of education for individuals who receive it? Growth theorists make human capital accumulation one of the cornerstones of their models and deal with different aspects of the role of human capital in growth [23]-[25]. Thus, the education-growth relationship has a theoretical foundation. Education gives workers greater adaptability to any change and reduces obsolescence of labour. Human capital affects economic growth and can help to develop economy through knowledge and the skills of people. From this point of view, human capital is interpreted as an investment which increases individual efficiency, hereby productivity and earnings.

The theoretical relationship between internet and economic growth has been well developed in a recent article by [9]. Internet development, according to this author, changes the way people work, socialize, create, share information and the way they organize transactions. Indeed, the internet firstly acts as an important incentive to the development of E-commerce business. E-commerce service provides marketing services, consulting services, and all related services and, consequently, helps enterprises and industries optimize the management of their activities. Secondly, the internet enhances the rapid dissemination of information and communication at low cost which is a considerable asset of technical innovation providing at the same time a good channel to the spread of new technologies. The third aspect of relationship between internet and economic growth emerges from the possible spillovers. The internet development is source of strong positive externalities since it constitutes a mean for industries and enterprises to learn from one another. Figure 2 below depicts explicitly these relationships.

\section{Variables Construction and Data Analysis}

The internet ( Internet $t_{i t}$ index ) is captured through a composite index named "internet network development index". Indeed, we apply the Principal Component Analysis (PCA) method to analyse three indicators related to internet (number of Internet users, Investment in telecoms with private participation amount, the rate of secure Internet servers) to construct a proxy of internet network development of each WAEMU_country. This proxy is supposed to represent the overall internet development degree of the considered country. We posit that the aggregation of these indicators reflects internet network development. Both the Kaiser-Meyer-Olkin $\left(\mathrm{KMO}^{1}\right)$ measure of sampling adequacy and Bartlett's test of sphercity [26] indicated that all the three variables included for the factor analysis were relevant. The variables included in the PCA come from World Bank Database.

${ }^{1}$ Kaiser-Meyer-Olkin (KMO) is a statistics that measures the adequacy of a variable to be included in factor analysis based on correlation and partial correlation. There is a KMO statistic for each individual variable, and their sum is the KMO overall statistic. KMO varies from 0 to 1.0 and KMO overall should be 0.60 or higher to proceed with factor analysis. If it is not, the lowest individual KMO statistic values will be adopted, until KMO overall rises above 0.60 . 


\section{INTERNET DEVELOPMENT}

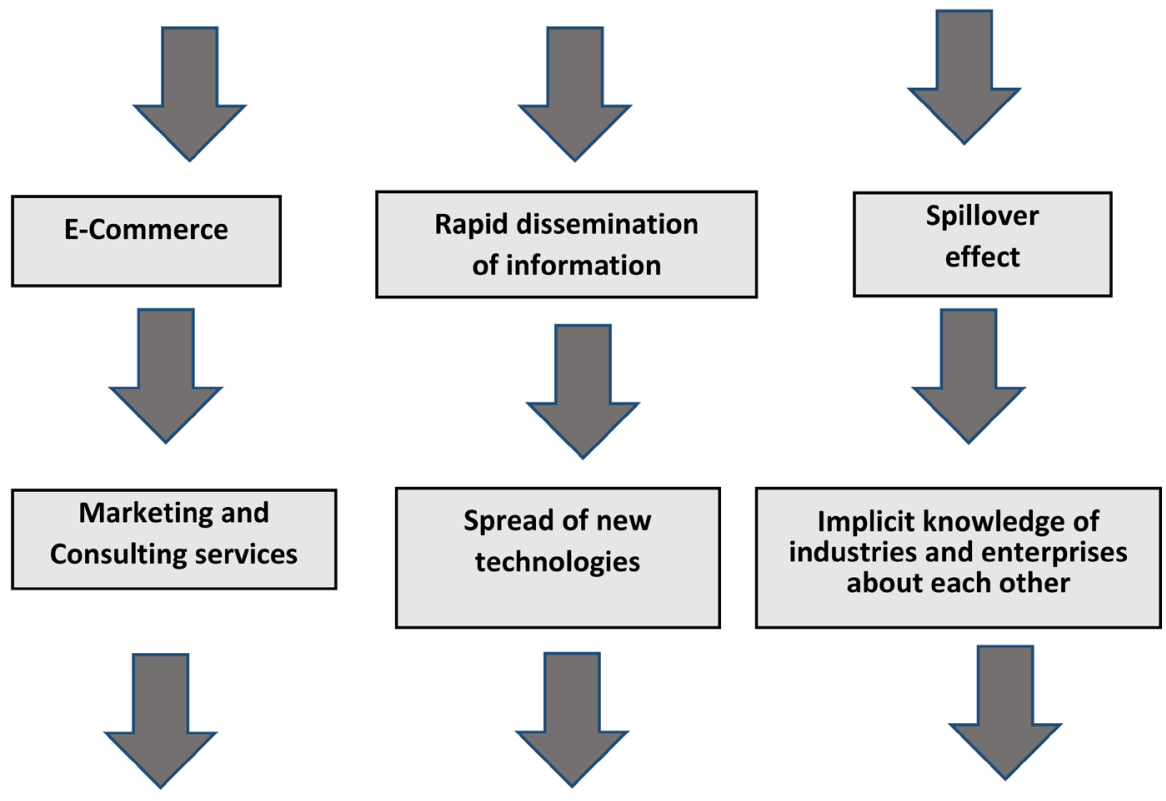

Increase of Labor and capital productivities

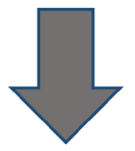

ECONOMIC GROWTH

Figure 2. Relationship between internet and economic growth. Source: Adapted from [9].

In order to capture the qualitative aspect of human capital in addition to the quantitative aspect, we built an index of human capital named human capital index (HC_index) using also the principal component analysis technique. The indicators considered in this exercise are: school expectancy, educational attainment of the population aged 25 years and older and the ratio of the number of teacher in primary school to the number of enrolment in primary school, average years of schooling in primary, in secondary and in higher school. These variables come from [27] [28] and the database constructed by [29]. The appropriate tests (Bartlett's test of sphercity and KaiserMeyer-Olkin measure of sampling adequacy) run on this set of variables reveal that all the variables included for human capital index construction were relevant.

The gross domestic product (GDP) comes from the [30], the technological progress (measure by the investment in research and development), the transportation capacity (measure by the road $\mathrm{km}$ ) and the stock of physical capital are taken from [28] database. These last variables are all considered in log function in order to interpret the associated parameters in terms of elasticities. The descriptive statistics of the variables used in this study are presented in Table 1 below. 
Table 1. The descriptive statistics.

\begin{tabular}{cccccc}
\hline Variables & Count & Mean & Max & Min & Sd \\
\hline lngdp & 42 & 10.63 & 13.73 & 9.34 & 1.35 \\
$\operatorname{lnK}$ & 42 & 27.73 & 28.72 & 26.32 & 0.57 \\
Internet_index & 42 & 3.47 & 5.02 & 0.48 & 1.96 \\
HC_index & 42 & 0.022 & 0.034 & 0.001 & 0.001 \\
lntrans & 42 & 3.17 & 7.40 & 2.13 & 1.17 \\
Intch & 42 & 4.39 & 19.37 & 0.26 & 4.81 \\
\hline
\end{tabular}

Source: Author's estimates based on data from WDI, 2016; PWT, 2015 and UNESCO, 2015.

Before proceeding to empirical estimations between GDP, Internet network development, human capital and other control variables, it is reasonable to figure out the correlation between the dependent variable (GDP in log) and the variables of interest (Human capital and Internet network development). Thus, Figure 3 provides insights regarding the correlation between these variables. From this figure, one can note that there is an explicit positive correlation between GDP and Internet network development, and between GDP and human capital. There seems however to exist outliers when one observe Figure 3 mainly in the right box. In a blind estimation procedure one would exclude them before estimating. In our case, it is likely that these seemingly outliers are not outliers since they belong to the same country. The gap between these values and others might be explained by country specific effects.

\section{Estimation Results and Discussion}

The choice between random and fixed effects models precedes estimation of panel data. To discriminate between the two estimation models we run the Hausman specification test where the null hypothesis is that the preferred model is the random effects versus the alternative the fixed effects [31]. The results of this test applied to our study indicate that the fixed effects model is superior to the random effects model (Prob (Chi2) $=$ $0.0434<0.05$ ). We consequently run the fixed effects model for analysis purpose. In addition, for the sake of robustness analysis we estimate two types of models: with controls and without controls. Table 2 and Table 3 present the results of the two types of estimations. Interestingly neither the type of variables having significant coefficient nor the level of significance do vary between the two types of results. This is a strong signal of the outputs robustness since the results obtained do not depend on the number of variables includes.

From the estimations we can conclude that the internet network, the human capital and the physical capital are economic growth drivers in WAEMU countries at current prevailing economic environment. Let us note before moving forwards that because the results presented in Table 2 are our preferred results, we will just concentrate on them for in-depth analysis. 

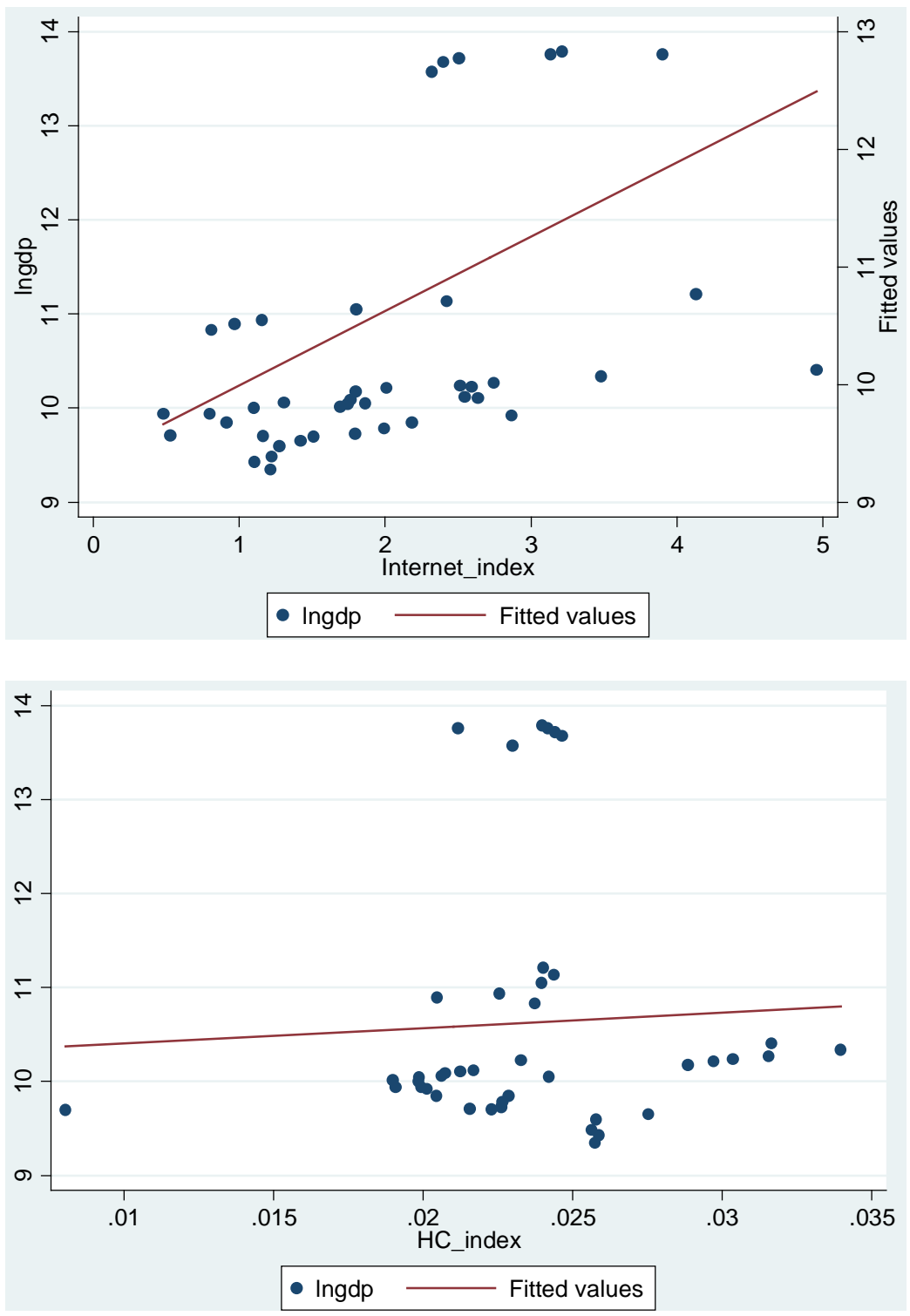

Figure 3. Relationship between the log function of GDP and the variables of interest. Source: Author, 2016. Drawn based on estimates in SPSS. The data come from UNESCO, 2015; WDI, 2016 and PWT, 2015.

Table 2. Results of the regression with control variables.

\begin{tabular}{cccc}
\hline Independent variables & Coef. & Std. Err & $\mathbf{P}>|\mathbf{t}|$ \\
\hline $\operatorname{lnK}$ & $\mathbf{0 . 1 1 6 2 ^ { * * * }}$ & 0.0288 & 0.000 \\
HC_index & $\mathbf{0 . 0 2 8 5 *}^{*}$ & 0.0152 & 0.071 \\
Internet_index & $\mathbf{0 . 8 5 2 0 ^ { * * * }}$ & 0.2351 & 0.001 \\
lntrans & 0.2674 & 2.1847 & 0.903 \\
lntch & 0.0021 & 0.0022 & 0.340 \\
Cons & $-5.8746^{*}$ & 3.3393 & 0.089 \\
\hline
\end{tabular}

Source: Author's estimates based on data from WDI, 2016; PWT, 2015 and UNESCO, 2015. Note: ${ }^{* * *}$ significant at $1 \%$ level, and ${ }^{*}$ significant at $10 \%$ level. 
Table 3. Results of the regression without control variables.

\begin{tabular}{cccc}
\hline Independent variables & Coef. & Std. Err & $\mathbf{P}>|\mathbf{t}|$ \\
\hline $\operatorname{lnK}$ & $0.115^{* * *}$ & 0.0279 & 0.000 \\
HC_index & $0.0285^{*}$ & 0.0142 & 0.071 \\
Internet_index & $0.8665^{* * *}$ & 0.2295 & 0.001 \\
lntrans & - & - & - \\
lntch & - & - & - \\
Cons & $-6.1196^{*}$ & 3.2422 & 0.068 \\
\hline
\end{tabular}

Source: Author's estimates based on data from WDI, 2016; PWT, 2015 and UNESCO, 2015. Note: ${ }^{* * *}$ significant at $1 \%$ level, and ${ }^{*}$ significant at $10 \%$ level.

Exactly going in-depth in the analysis, the results reveal that an increase of the internet network development index by 0.1 will trigger an increase of the real value of the gross domestic product by $8.5 \%$ on average. Thus this study points out internet network development as an important source of economic growth for WAEMU_countries. This result confirms to some extent the findings of a recent study by [9] which establishes that an increases of internet development index by 0.1 increases economic growth by $2.5 \%$ in the context of China. The higher impact found in the case of WAEMU_countries could be explained by the low internet development in these countries compare to Chinese context. The internet network impacts economic growth through the three channels that are E-commerce, dissemination of information and communication and positive externalities (the three channels are discussed in the Section 3).

The second source of economic growth established by this study is human capital. Indeed, 0.1 increase in human capital index increases economic growth by $0.2 \%$ on average. This figure is lower compare to the general findings from similar studies. The main reason could be that most of those studies ignore the qualitative aspect of human capital, this is not the case of this study. Thus, the low performance of human capital in terms of economic growth in WAEMU_countries can be interpreted as the result of the poor quality of education. An in-depth diagnostic of the quality of education policies in these countries is consequently needed.

The physical capital accumulation is another economic growth driver established by this paper. Considering the results of this study, 0.1 increases in physical capital increases real gross domestic product by $1.1 \%$ on average. This economic growth pillar has been established by various studies long time ego. However, the accumulation of physical capital is becoming more and more problematic, hence the search for new economic growth sources such as internet network development as established in this study.

\section{Conclusion}

To contribute to the search for new economic growth pillars in WAEMU countries except Gunea Bissau, this study investigated the role of internet network development in 
pursuing higher and sustainable economic growth and revisited the impact of human capital on gross domestic product. Based on panel data from diverse sources, we estimated a Cobb-Douglas function under the neoclassical Solow model which included constructed indices of internet network development and human capital by using fixed effects estimation technique. From the estimation, internet network development appears to be the main pillar for economic growth reinforcement of the union in the current economic prevailing environment. Thus, WAEMU countries should continue to increase infrastructure construction investment of internet communication technology, such as the so called internet $3 \mathrm{G}$. To strengthen the performance of the region in terms of economic growth, the member states also need to revisit and improve the quality of their educational systems. To improve the quality of the findings, future similar studies have to include additional factors in the construction of the internet network development index since the development of the internet is a dynamic, complex and multifaceted problem.

\section{References}

[1] Dewan, S. and Kraemer, K.L. (2000) Information Technology and Productivity: Evidence from Country-Level Data. Management Science, 46, 548-562.

http://dx.doi.org/10.1287/mnsc.46.4.548.12057

[2] Pohjola, M. (2002) The New Economy in Growth and Development. Oxford Review of Economic Policy, 18, 380-396. http://dx.doi.org/10.1093/oxrep/18.3.380

[3] Papaioannou, S.K. and Dimelis, S.P. (2007) Information Technology as a Factor of Economic Development: Evidence from Developed and Developing Countries. Economics of Innovation and New Technology, 16, 179-194. http://dx.doi.org/10.1080/10438590600661889

[4] Dedrick, J., Kraemer, K.L. and Shih, E. (2013) Information Technology and Productivity in Developed and Developing Countries. Journal of Management Information Systems, 30, 97-122. http://dx.doi.org/10.2753/MIS0742-1222300103

[5] Niebel, T. (2014) ICT and Economic Growth-Comparing Developing, Emerging and Developed Countries. ZEW Discussion Paper No. 14-117. http://ftp.zew.de/pub/zew-docs/dp/dp14117.pdf

[6] Loukou, A.F. (2005) Télécommunications et développement en côte d'ivoire à l'ère de la société de l'information et de la mondialisation. Doctorat Thesis, Universite Monpelleir III, Montpellier.

[7] Aker, J.C. and Mbiti, I.M. (2010) Mobile Phones and Economic Development in Africa. Journal of Economic Perspectives, 24, 207-232. http://dx.doi.org/10.1257/jep.24.3.207

[8] Commander, S., Harrison, R. and Menezes-Filho, N. (2011) ICT and Productivity in Developing Countries: New Firm-Level Evidence from Brazil and India. Review of Economics and Statistics, 93, 528-541. http://dx.doi.org/10.1162/REST_a_00080

[9] Feng, Y. (2016) Internet and Economic Growth: Evidence from Chinese Provincial Panel Data. Modern Economy, 7, 859-866. http://dx.doi.org/10.4236/me.2016.78089

[10] Zhao Z., Xiong, W. and Fang, J.X. (2016) Impact of Internet plus to China Economy, Development. Modern Economy, 7, 933-944. http://dx.doi.org/10.4236/me.2016.79096

[11] Barro, R.J. (2001) Human Capital and Growth. American Economic Review, 91, 12-17. http://dx.doi.org/10.1257/aer.91.2.12 
[12] Solow, R.M. (1956) A Contribution to the Theory of Economic Growth. Quarterly Journal of Economics, 70, 65-94. http://dx.doi.org/10.2307/1884513

[13] Islam, N. (1995) Growth Empirics: A Panel Data Approach. The Quarterly Journal of Economics, 110, 1127-1171. http://dx.doi.org/10.2307/2946651

[14] Pritchett, L. (2001) Where Has All the Education Gone? World Bank Economic Review, 15, 367-391. http://dx.doi.org/10.1093/wber/15.3.367

[15] Fuente A. and Doménech, R. (2002) Human Capital in Growth Regressions: How Much Difference Does Data Quality Make? An Update and Further Results. CEPR Discussion Paper No. 3587.

[16] Jorgenson, D.W. and Fraumeni, B.M. (1989) The Accumulation of Human and Non- Human Capital, 1948-1984. In: Lipsey, R.E. and Tice, H.S., Eds., The Measurement of Savings, Investment and Wealth, University of Chicago Press, Chicago, 227-282.

[17] Barro, R. (1991) Economic Growth in a Cross Section of Countries. The Quarterly Journal of Economics, 106, 407-443. http://dx.doi.org/10.2307/2937943

[18] Evlo, K. (1996) Capital humain et croissance économique au Togo: Une extension du modèle de Solow. Annales de P Université du Bénin, Série Droit et Sciences Economiques, 16, 68-86.

[19] Quenum, V.C. (2011) Niveaux d'éducation et croissance économique dans les pays de l'UEMOA. Revue d Economie Théorique et Appliquée, 1, 41-62.

[20] Hanushek, E.A. (2013) Economic Growth in Developing Countries: The Role of Human Capital. Economics of Education Review, 37, 204-212. http://dx.doi.org/10.1016/j.econedurev.2013.04.005

[21] Tchalim, T. (2015) Levels of Education and Economic Growth in Togo. African Integration and Development Review, 8, 1-27.

[22] Denisson, E.F. (1962) The Sources of Economic Growth in the US and the Alternatives before US. Committee for Economic Development, Committee for Economic Development edition, New York.

[23] Lucas, R. (1988) On the Mechanics of Economic Development. Journal of Monetary Economics, 22, 3-42. http://dx.doi.org/10.1016/0304-3932(88)90168-7

[24] Romer, P.M. (1988) Capital Accumulation in the Theory of Long Run Growth. RCER Working Papers from University of Rochester, Center for Economic Research (RCER).

[25] Aghion, P. and Hawitt, P. (1992) A Model of Growth through Creation Destruction. Econometrica, 60, 323-351. http://dx.doi.org/10.2307/2951599

[26] Hair, J., Anderson, R., Tatham, R. and Black, W. (1998) Multivariate Data Analysis. 5th Edition, Prentice Hall International, London.

[27] UNESCO (2015) UNESCO Databases of Resources on Education. http://data.uis.unesco.org/

[28] World Bank (2016) World Development Database. http://data.worldbank.org/products/wdi

[29] Barro, R. and Lee, J. (2013) A New Data Set of Educational Attainment in the World, 1950-2010. Journal of Development Economics, 104, 184-198. http://dx.doi.org/10.1016/j.jdeveco.2012.10.001

[30] Robert, C.F., Inklaar, R. and Timmer, M.P. (2015) The Next Generation of the Penn World Table. American Economic Review, 105, 3150-3182. www.ggdc.net/pwt

[31] Green, W. (2008) Econometric Analysis. 6th Edition, Prentice Hall, Upper Saddle River. 
Submit or recommend next manuscript to SCIRP and we will provide best service for you:

Accepting pre-submission inquiries through Email, Facebook, LinkedIn, Twitter, etc. A wide selection of journals (inclusive of 9 subjects, more than 200 journals)

Providing 24-hour high-quality service

User-friendly online submission system

Fair and swift peer-review system

Efficient typesetting and proofreading procedure

Display of the result of downloads and visits, as well as the number of cited articles

Maximum dissemination of your research work

Submit your manuscript at: http://papersubmission.scirp.org/

Or contact me@scirp.org 